Manufacture of Sulphuric Acid.

By Robert Hasenclever, Manager of the Stolberg Works.

In few branches of chemical technology is it possible to show an amount of progress equal to what has taken place in the manufacture of sulphuric acid during the last ten years. On the one hand, the production has been greatly augmented in consequence of the increased manufacture of soda, potash, by the preparation of artificial alizarin, nitro-glycerine, etc. On the other hand, the process of the manufacture of sulphuric acid has undergone essential alterations.

Whilst former investigations were chiefly undertaken in the hope of discovering new methods of procedure and new apparatus for the manufacture of sulphuric acid, attention has latterly been merely directed towards the discovery of new sources of sulphurous acid, of improved kilns, and of a theoretical elucidation of the process in the lead chambers-in use now for a century-with a view to its practical improvement.

Besides the memoirs of various chemists and technologists in the scientific journals the following works on the manufacture of sulphuric acid have appeared :-

1. M. J. Kolb, "Etude sur la Fabrication de l'acide Sulfurique Considerée au point de vue Theorique et Technologique." Lille, 1865. (Study on the manufacture of sulphuric acid considered from a theoretical and technological point of view.)

2. Dr. C. A. Winkler, "Untersuchungen über die Chemischen Vorgänge in den Gay-Lussac'schen Condensationsapparaten der Scwefelsäure-Fabriken." Freiburg, 1867. (Researches on the chemical processes in the Gay-Lussac columns in sulphuric acid works.)

3. "Handbuch der Chemischen Technologie. Herausgegeben von P. A. Bolley, band ii, 1. gruppe, von Dr. P. Schwarzenberg." Braunschweig, 1869. (Handbook of technological chemistry, edited by P. A. Bolley, vol. ii, group 1, by Dr. P. Sehwarzenberg.)

4. F. Bode, "Beiträge zur Theorie und Praxis der SchwefelsäureFabrikation." Berlin, 1872. (Contributions to the theory and practice of the manufacture of sulphuric acid.)

5. Henry Arthur Smith, "The Chemistry of the Sulphuric Acid Manufacture." London, 1873. (A German version by Fr. Bode, appeared at Freiburg, 1874.) 
6. Lorenzo Parodi, "Sull' Estrazione Dello Solfo in Sicilia, e Sugli Usi Industriali del Medesimo." Firenze, 1873. (On the extraction of sulphur in Sicily, and on its industrial uses.)

The number of the compounds of sulphur applicable in the manufacture of sulphuric acid has considerably increased in the last ten years. Sulphur is only used in a few establishments; the chief material being iron pyrites, and in certain cases galena, sulphuret of copper, copper pyrites, blende, and Laming's mass.

Concerning new arrangements of the sulphur kilns nothing has been published. We must remark, however, that in certain works the pyrites furnaces have been converted into sulphur burners by the simple substitution of plates of cast iron for the grate bars in consequence of the high price of pyrites in the years 1871-1873. Heidenreich, of Hanover, first converted his furnaces in the manner above mentioned, and burnt in twenty-four hours 120 kilos. of sulphur per square metre.

In Stettin, Hamburg, and other places, sulphuric acid has been latterly made from sulphur in place of pyrites. But with the fall in the price of the latter the use of sulphur has again been abandoned.

The export of sulphur from Sicily has latterly reached the figures given in the subjoined table:-

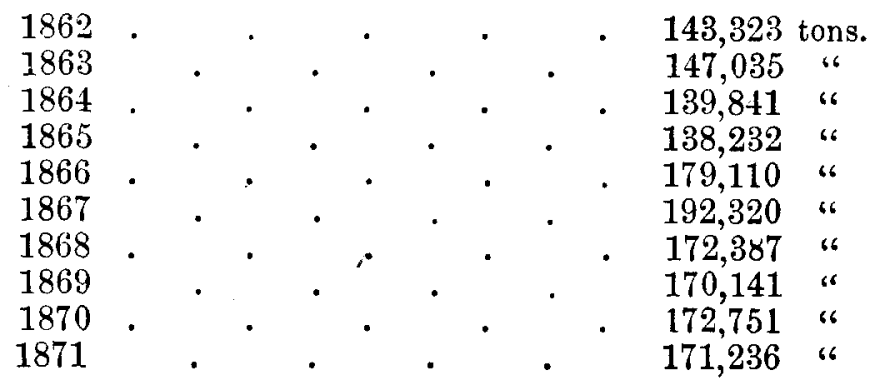

For many years sulphur has been largely used in the vineyards of France, Italy and Spain as a remedy for the grape disease. The increased production of gunpowder and ultramarine requires likewise great quantities of sulphur, so that the decreased consumption of sulphur due to the use of pyrites in the manufacture of sulphuric acid has scarcely depressed the exportation from Sicily.

Roasting Pyrites.-The application of iron pyrites for the manufacture of sulphuric acid is now almost universal, and the extraction of this mineral has greatly increased in the last ten years. The 
largest quantity is consumed in England, and comes from Spain, Portugal, and Norway. The imports of iron pyrites and Sulphur into Great Britain amounted in tons to :-

\begin{tabular}{|c|c|c|c|c|c|c|c|c|c|}
\hline \multicolumn{9}{|c|}{ Pyrites from- } & \multirow{2}{*}{$\begin{array}{l}\text { Sulphur } \\
\text { from } \\
\text { Eicily. }\end{array}$} \\
\hline Date. & Norway. & Germany. & Belgium. & Portugal. & & Italy. & $\begin{array}{l}\text { Sundry } \\
\text { Places. }\end{array}$ & Sum Total. & \\
\hline 1862 & 4,975 & 6,817 & 9,860 & 53,296 & 33,717 & & 2187 & 110 & 54,200 \\
\hline 1863 & 6,736 & 15,409 & 12,059 & 109,180 & 33,213 & & 2628 & 179,225 & 43060 \\
\hline$] 864$ & 16,087 & 12,751 & 7,069 & 118,489 & 15,529 & & 1005 & 170,990 & 40,420 \\
\hline 1865 & 22,229 & 14,727 & 2,121 & 137,787 & 16,3 & & 369 & 193,626 & 49,840 \\
\hline 1866 & 38,262 & 21,574 & 4,006 & 165,993 & 11,910 & & 7625 & 244,596 & 62,850 \\
\hline 1867 & 77,895 & 34,592 & 2,299 & 105,556 & 50,222 & & 2134 & 272,698 & 59,270 \\
\hline 1868 & 63,007 & 41,559 & & 75,883 & 47,458 & 794 & 1019 & 229,720 & 64,080 \\
\hline 1869 & 63,091 & 13,983 & & 140,805 & 99,648 & 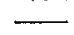 & 2420 & 819,947 & 51,580 \\
\hline 1870 & 67,464 & 14,914 & & 174,459 & 150,996 & & 3676 & 411,512 & 54,120 \\
\hline 1871 & 74,416 & 12,809 & & 120,573 & 242,163 & & 4581 & 454,542 & \\
\hline 1872 & 71,665 & 5,682 & 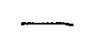 & 180,329 & 257,429 & & 2521 & 517,626 & \\
\hline
\end{tabular}

France derives its supply of pyrites chiefly from Chessy and Saint Bel, near Lyons; in the north, Belgian ores are used in small quantities. The pyrites consumed in Germany are chiefly produced from the "Sicilia" and "Siegena" mines, near Siegen; certain Rhenish mines produce also small quantities, such as the deposit of fine pyrites at Schwelm, Rammelsberg in the Harz district, etc.

The production of pyrites (in tons) in the following mines, amounted to:-

\begin{tabular}{|c|c|c|c|c|c|}
\hline & Belgium & $\begin{array}{l}\text { Chessy and } \\
\text { Saint Bel, } \\
\text { near Lyons. }\end{array}$ & Goslar. & Siegen. & $\begin{array}{l}\text { Total Prussian } \\
\text { mines except } \\
\text { Siegen \& Goslar. }\end{array}$ \\
\hline 1862 & & 45,973 & & 14,850 & 7461 \\
\hline 1863 & 36,244 & 59,699 & & 28,765 & 5934 \\
\hline 1864 & 29,956 & 61,103 & 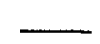 & 29,115 & 3437 \\
\hline 1865 & 31,818 & 63,538 & & 34,060 & 4187 \\
\hline 1866 & 55,004 & 65,222 & & 50,875 & 4302 \\
\hline 1867 & 41,298 & 75,653 & 1599 & 71,835 & 4756 \\
\hline 1868 & 37,933 & 75,656 & 2635 & 90,100 & 3953 \\
\hline 1869 & 31,670 & 91,020 & 2689 & 64,789 & 6394 \\
\hline 1870 & 28,665 & 63,464 & 3225 & 92,048 & 3191 \\
\hline 1871 & 42,272 & 68,797 & 3324 & 110,432 & 4574 \\
\hline 1872 & 40.932 & 99,000 & 3640 & 144.745 & $96 t$ \\
\hline 1873 & 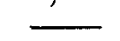 & 127,000 & 1217 & 123,172 & 3748 \\
\hline
\end{tabular}

The furnaces used in roasting iron pyrites vary according as they are intended for lumps, coarse, or small. The burners for lumps agree generally in the point that the ore is roasted on iron grate bars. The kilns employed in England have been repeatedly describedrecently by $\mathrm{H}$. A. Smith-and illustrated by diagrams. The indi- 
vidual furnaces are separated from each other by small vaults, and are connected in such a manner that the gases escaping into the lead chambers may have an approximately constant amount of sulphurous acid. Each compartment is closed below by a separate door, at which the spent ores are removed. These doors are closed when a fresh charge of pyrites is introduced into the kiln from above, whereby the escape of any considerable quantity of sulphurous acid during the opening of the upper door is prevented. If the difference of level between the kiln and the flue leading the gases into the chamber is considerable, air is drawn in and no sulphurous acid can escape on opening the working door.

(To be continued.)

\section{INVENTIONS OF THE CENTURY.}

[Abstract of the first lecture in Prof. Pliny E. Chase's course, on "Lessons of the Centennial," delivered before the Franklin Institute, March 6th, 1877.]

You will not expect me to rehearse in three lectures any considerable portion of the lessons which could be learned by six months'. study of the great Exhibition; but you may, perhaps, be interested in briefly reviewing a few of its most obvious teachings. I will ask you to-night to go back, in imagination, to the "good old times" of our grandfathers and great-grandfathers; to the generation which rejoiced in the enterprise of Franklin, who, as Deputy Postmaster General, had established a fast mail line, enabling a merchant or a stock broker or a lover, in Philadelphia, to send a letter to New York and get an answer in a week. There were no friction matches then. Man, as a cooking animal, had so far advanced from savagery as to substitute the flint and steel and tinder-box for the friction of two pieces of dry wood, as a means of procuring the fire that he needed. Matches, dipped in sulphur, served to start a flame from the tinder spark.

The German chemist, Döbereiner, found that platinum sponge occludes, or shuts up, many times its own volume of hydrogen. The rapid vibration of the gaseous particles being thus greatly concentrated, the frequent collisions raise the platinum to a glowing heat, 